\title{
Prevalence of suggestive images of carotid artery calcifications on panoramic radiographs and its relationship with predisposing factors
}

\author{
Prevalência de imagens sugestivas de calcificações \\ da artéria carótida em radiografias panorâmicas \\ e sua relação com fatores predisponentes
}

\author{
Ana Caroline Ramos de Brito ${ }^{1}$ \\ Helena Aguiar Ribeiro Nascimento ${ }^{1}$ \\ Rafaela Argento ${ }^{1}$ \\ Thamara Beline \\ Glaucia Maria Bovi Ambrosano ${ }^{1}$ \\ Deborah Queiroz Freitas ${ }^{1}$
}

${ }^{1}$ Faculdade de Odontologia de Piracicaba, Universidade Estadual de Campinas. Av. Limeira 901, Areião. 13414903 Piracicaba SP Brasil. acarolinerb@hotmail.com

\begin{abstract}
Panoramic radiographs (PR) can display radiopaque images suggestive of calcified atheroma in the carotid artery in asymptomatic patients. The aim of this study was to evaluate the prevalence of these images on $P R$ and their linkage with hypertension, obesity, age, gender and smoking habits. PR of 505 patients were evaluat$e d$. They were older than 30 years old and their $P R$ had been taken for different clinical reasons. Their body mass index was calculated; their waist circumference was also taken into consideration. Information about smoking habits and hypertension was obtained. The observers analyzed the presence of radiopaque mass in the region of the cervical vertebrae C3-C4 through the $P R$, confirmed by an antero-posterior (AP) radiograph. The results showed a $7.92 \%$ prevalence of suggestive images of calcifications on $P R$ and on AP radiograph. The adjusted Odds Ratio showed association with age and smoking habits. The calcification process is almost nine times higher for the elderly when compared to the young. As far as smokers are concerned, this process is twice worse when compared to no smokers. In conclusion, $7.92 \%$ of the group studied presented suggestive images of carotid atherosclerosis on $P R$, which is directly associated with the age and smoking habits.
\end{abstract}

Key words Panoramic radiograph, Arterial hypertension, Obesity, Stroke
Resumo As radiografias panorâmicas (RP) podem exibir imagens radiopacas sugestivas de ateromas calcificados na artéria carótida em pacientes assintomáticos. O objetivo deste estudo foi avaliar a prevalência destas imagens na RP e sua relação com hipertensão, obesidade, idade, sexo e tabagismo. Foram avaliadas RP de 505 pacientes acima de trinta anos, que realizaram esse exame por diversos motivos clínicos. Seu indice de massa corpórea foi calculado; sua circunferência abdominal também foi considerada. Informações sobre hipertensão e tabagismo foram obtidas. Os observadores avaliaram as RP para a presença de massas radiopacas na região das vértebras cervicais C3-C4, confirmadas por meio de uma radiografia ântero-posterior (AP). Os resultados mostraram prevalência de $7,92 \%$ de imagens sugestivas de calcificações em $R P$ e na radiografia AP. A razão de probabilidade (OR) ajustada mostrou associação com idade e tabagismo. O risco para as pessoas mais velhas aumenta até cerca de nove vezes quando comparado com aqueles mais jovens, enquanto para os fumantes, o risco é o dobro, quando comparado com não fumantes. Na população estudada, 7,92\% de todos os sujeitos apresentaram imagens sugestivas de aterosclerose carotídea em RP e houve associação com idade e tabagismo. Palavras-chave Radiografia panorâmica, Hipertensão, Obesidade, Acidente vascular cerebral 


\section{Introduction}

Cardiovascular diseases continue to be the main cause of morbidity and mortality worldwide. Cerebrovascular accidents are responsible for killing or disabling more than half a million Americans every year ${ }^{1}$. In Brazil, about 68,000 deaths per year are reported to be caused by stroke. This disease is the leading cause of death and disability in the country, generating significant economic and social impact ${ }^{2}$. People over 55 are at a great risk of having a stroke. This risk increases as they get older ${ }^{3}$.

Some studies have linked the presence of the carotid artery calcifications to systemic diseases such as obesity (body mass index and waist circumference), hypercholesterolaemia, hypertension, diabetes, renal stones, dental infections, prior atherosclerosis and with increasing age ${ }^{4-12}$.

Panoramic radiograph is one of the most requested complementary exam by dentists. Along with the evaluation of dental and maxillofacial hard tissues, panoramic radiograph can be used to spot soft tissue calcifications including calcified carotid artery atheroma ${ }^{13}$. The presence of calcified carotid artery plaque on panoramic images is an indicator of the risk of future adverse cardiovascular events ${ }^{5}$. Studies show that the prevalence of theses calcifications on panoramic radiographs taken for oral health reasons in the general dental outpatient groups, ranges from $2 \%$ to $5 \%{ }^{14}$. It is important to highlight that calcifications may not imply significant stenosis and not all atherosclerotic lesions are calcified. Despite that, the calcifications present on dental radiographs could be quite often associated with significant carotid diseases. This finding can be considered a cost-effective incentive for the use of Doppler sonography ${ }^{13}$.

When dentists are suspicious about the presence of carotid artery atheromas in panoramic radiographs, they play an important role for their patients' lives, as they guide and immediately refer their patients to doctors for adequate medical treatment ${ }^{15}$.

In recent years, a number of publications have detected calcifications on panoramic radiographs $s^{5,7-12,16-18}$. Although the diagnosis by panoramic radiography is reported, when it comes to the Brazilian population, no studies have analyzed the calcification prevalence and its association with risk factors.

The purpose of the present study is, therefore, to determine the prevalence of radiopacities suggestive of calcified atherosclerotic plaques on carotid artery on panoramic radiographs. Their association with hypertension, obesity, age, gender, smoking habits and history of cardiovascular diseases will also be studied.

\section{Methods}

The study was approved by the local ethics committee. Besides, formal consent was given by each subject. 505 patients agreed to take part in the research, all of them over their thirties (199 males and 306 females). The average of age being 50.1 years old. All patients were attended at the Department of Oral and Maxillofacial Radiology, Piracicaba Dental Scholl, during the years 2013-2014. PR were taken for different purposes regardless of this study.

Information about the lifestyle, such as smoking habits and medical history (hypertension, own cardiovascular disease or family history of cardiovascular disease, stroke or medication use) of each patient was assessed through a standardized questionnaire applied by a trained observer. Weight was measured to the nearest $0.1 \mathrm{~kg}$ while the subjects were dressed in light clothing. Height was measured to the nearest $0.1 \mathrm{~cm}$ with the subject in stocking feet.

Body mass index (BMI, $\left.\mathrm{kg} / \mathrm{m}^{2}\right)$ was calculated by dividing the body weight $(\mathrm{kg})$ by square of height $\left(\mathrm{m}^{2}\right)$, according to OMS, $2009^{19}$ :

1 - Malnourished: $<18.5$;

2 - Normal: 18.6 - 24.9;

3 - Overweigth: 25.0 - 29.9;

4 - Obesity: $>30.0$

Abdominal circumference was measured with the subject standing, at the midway between the lower rib margin and the iliac crest. The abdominal circumference was classified according to OMS, $2009^{19}$ :
Female:
Male:
1 - Ideal: $\leq 80.0$
$1-$ Ideal $: \leq 88.0$
2 - Increased: 80.0 - 93.92 - Increased: 89.0 - 101.9
3 - Substantial: $\geq 94.0 \quad 3$ - Substantial: $\geq 102.0$
Blood pressure was measured after at least 5 min of rest in the sitting position using a mer- cury sphygmomanometer. Notwithstanding the individuals who reported a state of hypertension previously diagnosed by a doctor and who were under medication to control blood pressure, were directly considered hypertensive.
All panoramic radiographs were obtained with an ORTHOPANTOMOGRAPH ${ }^{\circledR}$ OP100D (Instrumentarium Dental, Tuusula, Finland). The unit was operated with different parameters, 
depending on the patient's estimated jaw size.

Two oral and maxillofacial radiologists interpreted all the panoramic radiographs. The presence of carotid artery calcifications appeared as heterogeneous radiopacities in a verticolinear orientation adjacent to the hyoid bone, epiglottis and cervical vertebrae either at, above or below the intervertebral space between C3 and C4. Each observer interpreted each panoramic radiograph individually, this followed a discussion of each image between the two observers. If the two observers agreed, a positive diagnosis was made.

The patients whose cases were defined as positive by the two examiners (Figure 1) were asked to undergo a modified anterior-posterior (AP) radiograph (with chin elevated) (Figure 2) in order to confirm or refute the suggested findings on the panoramic radiograph. If the AP confirmed the calcification, the individual was referred to the cardiologist evaluation and if possible to realize carotid Doppler ultrasound.

The data analysis was performed by SAS (9.1.3 version; SAS Institute Inc., Cary, NC, USA). The crude logistic regression was performed to analyze the association between presence and laterality of calcification and different factors studied (gender, age, BMI, abdominal circumference, hypertension, smoking and own or family medical history of cardiovascular diseases). Variables with $p<0.05$ in the crude analysis were selected for initial inclusion in the multivariate logistic regression to determine the independent predictors of the presence of calcification.

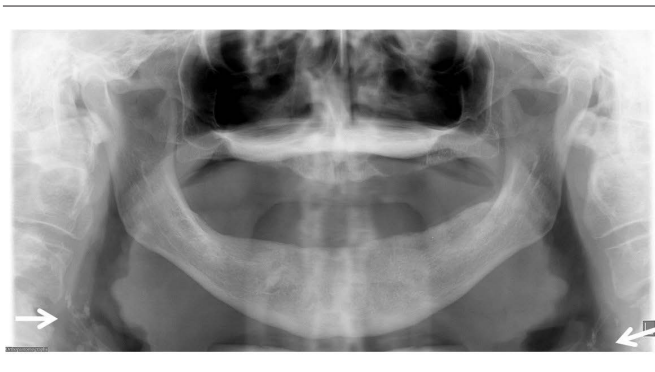

Figure 1. Panoramic radiograph of a 63-year-old male patient with heterogeneous radiopacities (arrows), in the left and right sides, adjacent to the hyoid bone and intervertebral space between $\mathrm{C} 3$ and $\mathrm{C} 4$, posterior to the angle of the mandible.

\section{Results}

The prevalence of suggestive images of calcifications on $\mathrm{PR}$, confirmed by $\mathrm{AP}$ radiograph, was $7.92 \%$ in the total of individuals; of these, $32.5 \%$ were male and $67.5 \%$ were female. In the male population, there was a $6.53 \%$ prevalence, while in the female group it was $8.82 \%$.

The presence of calcifications according to the predisposing factors studied is presented in Table 1. Subjects with calcifications were older and had a higher BMI and abdominal circumference. They also were hypertensive, had a history of cardiovascular disease and smoking habits. However, BMI, abdominal circumference and history of cardiovascular disease were not significantly associated with calcifications $(p>0.05)$. The brute regression showed that the presence of calcification was associated with age, hypertension and smoking habits.

Table 2 shows the distribution of uni and bilateral cases of calcifications detected on PR and the factors studied; there was no correlation between the factors and laterality.

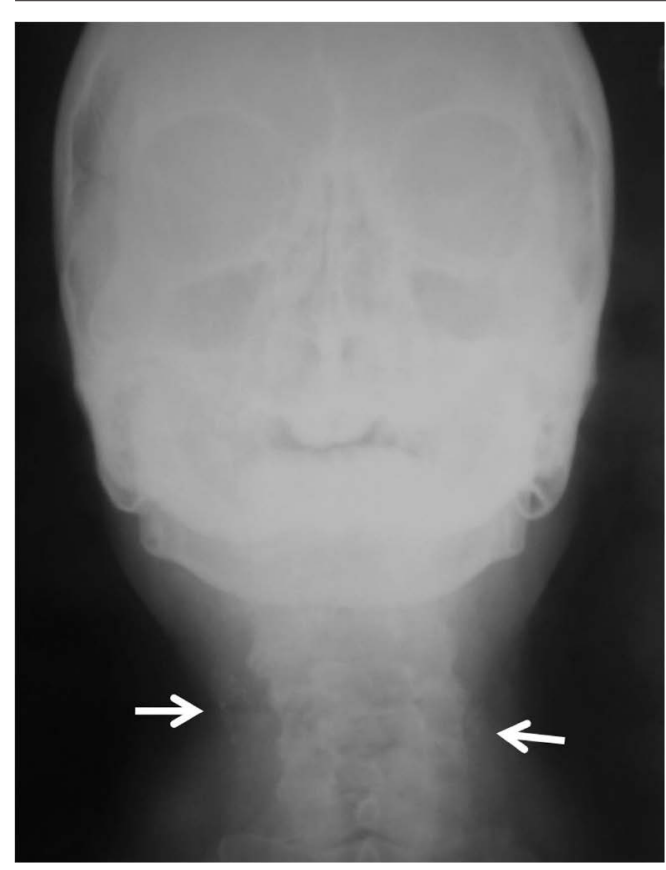

Figure 2. Modified anterior-posterior (AP) radiograph (with chin elevated) showing calcifications in the area of the carotid (arrows) adjacent to the cervical spine, bilaterally. 
Table 1. Brute logistic regression for presence of calcification.

\begin{tabular}{|c|c|c|c|c|c|c|c|}
\hline \multirow[b]{2}{*}{ Variables } & \multicolumn{2}{|c|}{ Sample } & \multicolumn{2}{|c|}{ Calcification } & \multirow[b]{2}{*}{ OR brute } & \multirow[b]{2}{*}{ CI 95\% } & \multirow[b]{2}{*}{$p$} \\
\hline & $\mathbf{n}$ & $\%$ & $\mathbf{n}$ & $\%$ & & & \\
\hline \multicolumn{8}{|l|}{ Gender } \\
\hline Male & 199 & 39.41 & 13 & 6.53 & 1 & & \\
\hline Female & 306 & 60.59 & 27 & 8.82 & 1.38 & $0.70-2.75$ & 0.45 \\
\hline \multicolumn{8}{|l|}{ Age (years) } \\
\hline $30-45$ & 185 & 36.63 & 5 & 2.70 & 1 & & \\
\hline $46-60$ & 219 & 43.37 & 15 & 6.85 & 2.65 & $0.94-7.43$ & $<0.0001$ \\
\hline $61-80$ & 101 & 20.00 & 20 & 19.80 & 8.89 & $3.22-24.51$ & 0.0011 \\
\hline \multicolumn{8}{|l|}{ BMI $\left(\mathrm{Kg} \mathrm{m}^{2}\right)$} \\
\hline Normal & 164 & 32.48 & 12 & 7.32 & 1 & & \\
\hline Overweight & 198 & 39.21 & 15 & 7.58 & 1.03 & $0.47-2.29$ & 0.72 \\
\hline Obesity & 143 & 28.32 & 13 & 9.09 & 1.27 & $0.56-2.87$ & 0.76 \\
\hline \multicolumn{8}{|l|}{ Abd circumf. } \\
\hline Ideal & 77 & 15.25 & 4 & 5.19 & 1 & & \\
\hline Increased & 203 & 40.20 & 15 & 7.39 & 1.45 & $0.47-4.53$ & 0.37 \\
\hline Substantial & 225 & 44.55 & 21 & 9.33 & 1.87 & $0.62-5.66$ & 0.58 \\
\hline \multicolumn{8}{|l|}{ Hypertension } \\
\hline Yes & 136 & 26.93 & 19 & 13.97 & 2.69 & $1.39-5.18$ & \\
\hline No & 369 & 73.07 & 21 & 5.69 & 1 & & 0.0041 \\
\hline \multicolumn{8}{|l|}{ Smoking } \\
\hline Yes & 95 & 18.81 & 13 & 13.68 & 2.25 & $1.11-4.54$ & \\
\hline No & 410 & 81.19 & 27 & 6.59 & 1 & & 0.0359 \\
\hline \multicolumn{8}{|l|}{ Pat PH } \\
\hline Yes & 17 & 3.37 & 3 & 17.65 & 2.61 & $0.71-9.50$ & \\
\hline No & 488 & 96.63 & 37 & 7.58 & 1 & & 0.29 \\
\hline \multicolumn{8}{|l|}{ Fam PH } \\
\hline Yes & 139 & 27.52 & 13 & 9.35 & 1.29 & $0.65-2.59$ & 0.58 \\
\hline No & 366 & 72.48 & 27 & 7.38 & 1 & & \\
\hline
\end{tabular}

BMI: Body mass índex; Abd circumf.: Abdominal circumference; Pat PH: Patient previous history of cardiovascular disease; Fam PH: Family previous history of cardiovascular disease; OR: Odds ratio; CI: Confidence interval.

When these same parameters were adjusted, the strength of the association was attenuated for hypertension, but remained statistically significant for age and smoking habits (Table 3). Concerning to age, it was observed that the risk for older people increases up to almost nine times when compared to young. For smokers, the risk is twice when compared with no smokers.

\section{Discussion}

Atherosclerotic tend to accumulate, in form of irregular plaques, within the bifurcation of the common, external, and internal carotid arteries. However, not all atherosclerotic lesions are calcified; furthermore, the presence of calcification in this location is not a definitive indicator of vascular disease ${ }^{14}$. Because of its anatomical position, this region can be viewed on panoramic radiographs, which is a radiographic modality com- monly requested in dentistry. As atherosclerosis may be an asymptomatic condition, it may be an incidental finding on routine panoramic examination of the patient.

As other calcifications can appear in the same region of atheroma on panoramic radiograph, which may be anatomic (hyoid bone, cartilage triticeous, epiglottis, etc.) or pathologic (calcified lymph nodes, tonsilloliths, phleboliths, etc. $)^{3}$, it is necessary another radiographic (AP) or exam for the diagnosis to be confirmed.

The gold standard for the detection of atheroma is ultrasonography with Doppler; the panoramic radiograph cannot be considered an accurate test for stenosis, but a finding on radiography requires referral to a specialist for diagnosis, because there is a connection between findings in panoramic radiography and cardiovascular events $^{16}$. Thus, the panoramic radiograph may be a risk marker for subsequent cardiovascular events $^{12}$; moreover, previous studies have found 
a correlation between calcifications found in the panoramic radiograph with the findings on ultrasonography ${ }^{6,13,15,20,21}$ and others also used the

Table 2. Brute logistic regression for laterality of calcification.

\begin{tabular}{|c|c|c|c|c|c|}
\hline \multirow[b]{2}{*}{ Variables } & \multicolumn{2}{|c|}{ Unilateral } & \multicolumn{2}{|c|}{ Bilateral } & \multirow[b]{2}{*}{$p$} \\
\hline & $\mathbf{n}$ & $\%$ & $\mathbf{n}$ & $\%$ & \\
\hline \multicolumn{6}{|l|}{ Gender } \\
\hline Male & 10 & 76.92 & 3 & 23.08 & \\
\hline Female & 15 & 55.55 & 12 & 44.45 & 0.3377 \\
\hline \multicolumn{6}{|l|}{ Age (years) } \\
\hline $30-45$ & 3 & 60.00 & 2 & 40.00 & 0.7866 \\
\hline $46-60$ & 10 & 40.00 & 5 & 60.00 & 0.9597 \\
\hline 61-80 & 12 & 60.00 & 8 & 40.00 & \\
\hline \multicolumn{6}{|l|}{$\mathrm{BMI}\left(\mathrm{Kg} \mathrm{m}^{2}\right)$} \\
\hline Normal & 8 & 66.67 & 4 & 33.33 & 0.7705 \\
\hline Overweight & 8 & 53.33 & 7 & 46.67 & 0.6376 \\
\hline Obesity & 9 & 69.23 & 4 & 30.77 & \\
\hline \multicolumn{6}{|l|}{ Abd circumf. } \\
\hline Ideal & 2 & 50.00 & 2 & 50.00 & 0.7751 \\
\hline Increased & 11 & 73.33 & 4 & 26.67 & 0.5188 \\
\hline Substantial & 12 & 57.14 & 9 & 42.86 & \\
\hline \multicolumn{6}{|l|}{ Hypertension } \\
\hline Yes & 13 & 68.42 & 6 & 31.58 & \\
\hline No & 12 & 57.14 & 9 & 42.86 & 0.6827 \\
\hline \multicolumn{6}{|l|}{ Smoking } \\
\hline Yes & 8 & 61.54 & 5 & 38.46 & \\
\hline No & 17 & 62.96 & 10 & 37.04 & 0.7937 \\
\hline \multicolumn{6}{|l|}{ Pat PH } \\
\hline Yes & 2 & 66.67 & 1 & 33.33 & \\
\hline No & 23 & 62.16 & 14 & 37.84 & 0.6419 \\
\hline \multicolumn{6}{|l|}{ Fam PH } \\
\hline Yes & 6 & 46.15 & 7 & 53.85 & \\
\hline No & 19 & 70.37 & 8 & 29.63 & 0.2572 \\
\hline
\end{tabular}

BMI: Body mass índex; Abd circumf.: Abdominal circumference.; Pat PH: Patient previous history of cardiovascular disease; Fam PH: Family previous history of cardiovascular disease. panoramic radiograph to evaluate the prevalence of atheroma ${ }^{4,16}$.

In this study, the differential diagnosis were made by the AP radiograph, a method also used by Henriques et al. ${ }^{22}$ and Almog et al. ${ }^{3}$. This aimed the diagnosis, because radiopacities suggestive of calcified atherosclerotic plaques on carotid artery is displayed laterally to the vertebra, while the images of other structures of average body region, as calcification in the triticeous cartilage, which is the greatest cause of erroneous diagnosis of atheroma ${ }^{23}$, are overlapping to the spine. This was the method available in the Radiology Clinic where the study was conducted; so the patient could not perform an ultrasound of the neck immediately for confirmation of the presence of atheroma and, when the radiopaque image had been viewed, the patient was referred to an appropriate doctor.

The population studied was in their thirties. In younger patients, only a minor number of cases with carotid calcifications can be found ${ }^{16}$. Despite this, the accumulation of calcium in the aorta starts to occur after the person is twenty years old. That is why it was decided to include younger patients, so almost all age groups with possibility of having calcification in the carotid artery could be analyzed.

The results of this study demonstrate that $7.92 \%$ of the subjects showed a calcified carotid artery atheroma, which was confirmed by AP radiograph. Previous studies have found a prevalence of carotid calcification on panoramic radiographs close to this study's results, ranging from $5.6 \%$ to $6.8 \%{ }^{9,15,18}$, while other studies obtained lower values of $1.6 \%$ to $4.8 \% 0^{8,13,16,17,24}$. However, in some specific conditions, such as patients with primary hyperparathyroidism, kidney stones and cardiovascular disease symptoms, the prevalence was higher ${ }^{4,8,18}$.

Table 3. Multivariate logistic regression analysis for presence of calcification.

\begin{tabular}{|c|c|c|c|c|c|c|c|}
\hline \multirow[b]{2}{*}{ Variables } & \multicolumn{2}{|c|}{ Sample } & \multicolumn{2}{|c|}{ Calcification } & \multirow{2}{*}{$\begin{array}{c}\text { OR } \\
\text { adjusted }\end{array}$} & \multirow[b]{2}{*}{ CI 95\% } & \multirow[b]{2}{*}{$p$} \\
\hline & $\mathbf{n}$ & $\%$ & $\mathbf{n}$ & $\%$ & & & \\
\hline \multicolumn{8}{|l|}{ Age (years) } \\
\hline $30-45$ & 185 & 36.63 & 5 & 2.70 & 1 & & \\
\hline $46-60$ & 219 & 43.37 & 15 & 6.85 & 2.61 & $0.91-7.42$ & $<0.001$ \\
\hline $61-80$ & 101 & 20.00 & 20 & 19.80 & 8.87 & $3.19-24.50$ & 0.0010 \\
\hline \multicolumn{8}{|l|}{ Smoking } \\
\hline Yes & 95 & 18.81 & 13 & 13.68 & 2.23 & $1.12-4.51$ & \\
\hline No & 410 & 81.19 & 27 & 6.59 & 1 & & 0.0169 \\
\hline
\end{tabular}

OR: Odds ratio; CI: Confidence interval. 
Gender, age, obesity, waist circumference, hypertension, previous history of cardiovascular disease and patient's family history and smoking habits were the risk factors studied, but only the association between calcification, age and smoking habits were significant. Other studies had also showed a correlation with age ${ }^{13,18,25}$. In fact, in a Turkey population, in addition to the age, it was found correlation with gender (male), family history of cardiovascular disease and dyslipidemia; moreover, there was no correlation with hypertension and smoking habits ${ }^{24}$. These discrepancies in the predictors factors could be attributed to differences in the populations' studies. Indeed, the authors analyzed symptomatic patients of a Cardiologic department whereas this study analyzed asymptomatic patients who were referred to a panoramic radiograph for dental treatment, representatives of as small portion of the Brazilian population (very heterogeneous), in the city of Piracicaba/SP with a medium income and without specific diseases. When the relationship was studied according to specific conditions, such as in patients with primary hyperparathyroidism, despite the prevalence being of $40 \%$, there was no correlation with atherogenic pattern (age, body mass index, hypertension, diabetes, hyper- lipidemia) $)^{3}$. Postmenopausal Women over 50 years old, for its part, showed $11 \%$ of prevalence of carotid calcification, also not correlated with hypertension, past history of myocardial infarction and hypercholesterolemia ${ }^{10}$.

It is crucial for the dental practitioners to know the characteristics and prevalence of carotid artery calcifications to perform a thorough evaluation of areas of panoramic radiograph, which can identify such calcifications. Furthermore, the professionals should differentiate these calcifications from the others when it is possible to perform an AP radiography ${ }^{26}$. Consequently, when their presence is suspected or confirmed, the patient has to be informed of the findings and its implications. He has also to be referred to a medical evaluation. To this end, patients with smoking history require special attention.

\section{Conclusions}

The study came to the conclusion that, among the factors studied, only the age and smoking habits were correlated to the presence of suggestive images of atheroma in PR. Besides, this prevalence was of $7.92 \%$ of all the individuals assessed.

\section{Collaborations}

ACR Brito, HAR Nascimento, R Argento, T Beline, GMB Ambrosano, DQ Freitas all participated in the preparation and performance of the tests, the analysis of results and the composition of the article for publication. 


\section{References}

1. American Heart Association. Heart and stroke statistical update. Dallas: American Heart Association; 2002.

2. Portal Brasil. Saúde. Acidente vascular cerebral (AVC). [cited 2015 Apr 1]. Available in: http://www.brasil.gov. br/saude/2012/04/acidente-vascular-cerebral-avc.

3. Almog DM, Tsimidis K, Moss ME, Gottlieb RH, Carter LC. Evaluation of a training program for detection of carotid artery calcifications on panoramic radiographs. Oral Surg Oral Med Oral Pathol Oral Radiol Endod 2000; 90(1):111-117.

4. Friedlander AH, Aghazadehsanai N, Chang TI, Harada N, Garret NR. Prevalence of calcified carotid artery atheromas on panoramic images of individuals with primary hyperparathyroidism. Dentomaxillofac Radiol 2013; 42(8):20130118.

5. Friedlander AH, Golub MS. The significance of carotid artery atheromas on panoramic radiographs in the diagnosis of occult metabolic syndrome. Oral Surg Oral Med Oral Pathol Oral Radiol Endod 2006; 101(1):95101.

6. Friedlander AH, Sung EC, Chung EM, Garret, NR. Radiographic quantification of chronic dental infection and its relationship to the atherosclerotic process in the carotid arteries. Oral Surg Oral Med Oral Pathol Oral Radiol Endod 2010; 109(4):615-621.

7. Friedlander AH, Garrett NR, Norman DC. The prevalence of calcified carotid artery atheromas on the panoramic radiographs of patients with type 2 diabetes mellitus. J Am Dent Assoc 2002; 133(11):1516-1523.

8. Üstun I, Inci M, Demirtas A, Sisman Y, Gökçe C, Tarim Ertas E. Prevalence of carotid artery calcification on panoramic radiographs in patients with renal stones. Turk Med Sci 2013; 43(5):706-710.

9. Lee JS, Kim OS, Chung HJ, Kim YJ, Kweon SS, Lee YH, Shin MH, Yoon SJ. The prevalence and correlation of carotid artery calcification on panoramic radiographs and peripheral arterial disease in a population from the Republic of Korea: the Dong-gu study. Dentomaxillofac Radiol 2013; 42:29725099.

10. Taheri JB, Moshfeghi M. Prevalence of calcified carotid artery on panoramic radiographs in postmenopausal women. J Dent Res Dent Clin Dent Prospect 2009; 3(2):46-51.

11. Tanaka T, Morimoto Y, Ansai T, Okabe S, Yamada K, Taguchi A, Awano S, Kito S, Takata Y, Takehara T, Ohba T. Can the presence of carotid artery calcification on panoramic radiographs predict the risk of vascular diseases among 80-years-olds? Oral Surg Oral Med Oral Pathol Oral Radiol Endod 2006; 101(6):777-783.

12. Cohen SN, Friedlander AH, Jolly DA, Date L. Carotid calcification on panoramic radiographs: an important marker for vascular risk. Oral Surg Oral Med Oral Pathol Oral Radiol Endod 2002; 94(4):510-514.

13. Imanimoghaddam M, Rooh MR, Hashemi EM, Blouri AJ. Doppler sonography confirmation in patients showing calcified carotid artery atheroma in panoramic radiography and evaluation of related risk factors. $J$ Dent Res Dent Clin Dent Prospect 2012; 6(1):6-11.

14. Almog DM, Horev T, Illig KA, Green RM, Carter LC. Correlating carotid artery stenosis detected by panoramic radiography with clinically relevant carotid artery stenosis determined by duplex ultrasound. Oral Surg Oral Med Oral Pathol Oral Radiol Endod 2002; 94(6):768-773.
15. Johansson EP, Ahlqvist J, Garoff M, Karp K, Jäghagen EL, Wester P. Ultrasound screening for asymptomatic carotid stenosis in subjects with calcification in the area of the carotid arteries on panoramic radiographs: a cross-sectional study. BMC Cardiovascular Disorders 2011; 11(44):1-9.

16. Bayer F, Helfgen EH, Bos C, Kraus D, Enkling N, Mues $S$. Prevalence of findings compatible with carotid artery calcifications on dental panoramic radiographs. Clin Oral Invest 2011; 15(4):563-569.

17. Sisman Y, Ertas ET, Gokce C, Menku A, Ulker M, Akgunlu F. The prevalence of carotid artery calcification on the panoramic radiographs in Cappadocia region population. Eur J Dent 2007; 1(3):132-138.

18. Sunman H, Yorgun H, Canpolat U, Hazırolan T, Kaya EB, Ateş AH, Dural M, Aytemir K, Tokgözo lu L, Kabakçı G, Akata D, Oto A. Association between family history of premature coronary artery disease and coronary atherosclerotic plaques shown by multidetector computed tomography coronary angiography. Int $J$ Cardiol 2013; 164(3):355-358

19. Associação brasileira para o estudo da obesidade e da síndrome metabólica (ABESO). Diretrizes brasileiras de obesidade 2009/2010. 3a ed. Itapevi: AC Farmacêutica; 2009.

20. Romano-Sousa CM, Krejci L, Medeiros FMM, Graciosa-Filho RG, Martins MFF, Guedes VN, Fenyo-Pereira M. Diagnostic agreement between panoramic radiographs and color doppler images of carotid atheroma.J Appl Oral Sci 2009; 17(1):45-48.

21. Friedlander AH, Garrett NR, Chin EE, Baker JD. Ultrasonographic confirmation of carotid artery atheromas diagnosed via panoramic radiography. J Am Dent Assoc 2005; 136(5):682-683.

22. Henriques JCG, Kreich EM, Baldani MH, Luciano M, Castilho JCM, Moraes LC. Panoramic radiography in the diagnosis of carotid artery atheromas and the associated risk factors. Open Dent J 2011; 5:79-83.

23. Kamikawa RS, Pereira MF, Fernandes A, Meurer MI. Study of the localization of radiopacities similar to calcified carotid atheroma by means of panoramic radiography. Oral Surg Oral Med Oral Pathol Oral Radiol Endod 2006; 101(3):374-378.

24. Bayram B, Uckan S, Acikgoz A, Müderrisoglu H, Aydinalp A. Digital panoramic radiography: a reliable method to diagnose carotid artery atheromas? Dentomaxillof Radiol 2006; 35(4):266-270.

25. Horsley SH, Beckstrom B, Clark SJ, Scheetz JP, Khan Z, Farman AG. Prevalence of carotid and pulp calcifications: a correlation using digital panoramic radiographs. Int J Cars 2009; 4(2):169-173.

26. MacDonald D, Chan A, Harris A, Vertinsky T, Farman AG, Scarfe WC. Diagnosis and management of calcified carotid artery atheroma: dental perspectives. Oral Surg Oral Med Oral Pathol Oral Radiol 2012; 114(4):533547.

Artigo apresentado em 22/05/2015

Aprovado em 22/08/2015

Versão final apresentada em 24/08/2015 
